\title{
Role of adjuvant metformin therapy on HA1C in type 1 diabetes: A systematic
}

\section{review}

Ibrahim Mahmoud Ajwah ${ }^{1}$, Mona Musalm Alatawi ${ }^{1}$, Maram Ibrahim Alanazi ${ }^{1}$, Ruaa Omar Nughays $^{1}$, Samaher Ibrahim Alaauldeen ${ }^{1}$, Lamees Aimen Maghrabi ${ }^{1}$, Arwa Ibrahim Ramel ${ }^{1}$, Hanadi Hezam Althobiati ${ }^{1}$, Fahad Mobarak Alqahtani ${ }^{1}$, Nawaf Abdulkarim Aldhuwayhi ${ }^{1}$, Ebtihal Hassan Bin Selim ${ }^{1}$, and Roaid Khan ${ }^{2}$

1. Internal Medicine Residents, Saudi Commission for Health Specialties, Kingdom of Saudi Arabia

2. Internal Medicine and Endocrine consultants, King Salman Armed Forced Hospital, Tabuk, kingdom of Saudi Arabia

\section{RESEARCH}

Please cite this paper as: Ajwah I, Alatawi M, Alanazi $M$, Nughays R, Alaauldeen S, Maghrabi L, Ramel A, Althobiati $H$, Alqahtani F, Aldhuwayhi N, Selim E, Khan R. Role of Adjuvant metformin Therapy on HA1C in type 1 diabetes: A systematic review. AMJ 2020;13(5):182-188.

https://doi.org/10.35841/1836-1935.13.5.182-188

\section{Corresponding Author:}

Ibrahim Mahmoud Ajwah

King Salman Armed Forced Hospital PO Box 3458 Tabuk

51937, Saudi Arabia

Email: aj.wa@hotmail.com

\section{ABSTRACT}

\section{Background}

Adequate glycaemic control is a protective strategy against diabetic complication that achieved manly with insulin therapy, studies have shown that type 1 diabetic patients had a reduced insulin sensitivity, on view of this fact, metformin as an insulin sensitizing agent was used in trials as an adjuvant medication to the insulin.

\section{Aims}

Current study aimed to summarize the benefit of adjuvant metformin on HA1C in type 1 diabetes on glycaemic control.

\section{Methods}

A systematic electronic search was conducted including the Pub Med, Google Scholar, and EBSCO using the following terms in different combinations: metformin, diabetes, HA1C, and $\mathrm{C}$ - peptide. Out of two hundred and four articles, only six were included.

\section{Results}

Six randomized control trials were identified, aimed to investigate the role of adjuvant metformin on glycaemic control in type 1 diabetes patients. Metformin in dose ranging between $1-2 \mathrm{~g}$ per day were used for at least three months. Significant HA1c reduction was shown in two out of six trials.

\section{Conclusion}

Administering adjunctive metformin therapy in type 1 diabetic patients associated with modest reduction in HA1c, improve insulin resistance as indicated by reduce daily insulin requirement.

\section{Key Words}

Diabetes, metformin, insulin

\section{What this study adds:}

\section{What is known about this subject?}

Type 1 diabetes threated manly by intensive insulin regiment in form of multiple daily injection or insulin pump.

\section{What new information is offered in this study?}

Oral antidiabetic medication that approved in type 2 diabetes may play a role in treating type 1 diabetic patents.

3. What are the implications for research, policy, or practice?

Intensive insulin therapy is the cornerstone in managing type 1 diabetic patients, metformin as well as other oral agents still investigatory medication.

\section{Background}

Together, macrovascular atherosclerotic complication along 
with microvascular disease in form of retinopathy, nephropathy, and neuropathy are a consequence of poor glycaemic control. ${ }^{1-3}$ Adequate glycaemic control is the corner stone to avoid such consequence. Moreover, American Diabetic Association (ADA) recommend a targeted A1c of $<7$ per cent in absence of hypoglycaemia, through initiation of intensive insulin regimens, either via multiple daily injections or continuous subcutaneous insulin infusion. ${ }^{4}$

Despite the novel approaches of insulin treatment such as insulin pumps, continuous glucose monitoring, and hybrid closed-loop systems, majority of those with type 1 diabetes (T1D) have suboptimal glycaemic control. As a result, to achieve the optimal control, adjunctive noninsulin medications were used in observational and few randomized control trials (RCTs). ${ }^{5-7}$

Patient with type one diabetes can have insulin resistance mainly due to obesity, lack of exercise and puberty. ${ }^{8}$

Increase insulin dose requirement is needed in management of insulin resistant diabetes and that might lead to noncompliance and poor glycaemic control. ${ }^{9}$

Metformin is an oral medication that commonly used in type 2 diabetes. It increases insulin sensitivity by increasing insulin uptake and utilization in skeletal muscle and decrease hepatic glucose production, metformin leads to decrease insulin dose requirement in type two diabetes. ${ }^{10}$

The effects of metformin in addition to insulin therapy in type one diabetes still under debate. The previous limited studies showed that adding metformin to insulin in type one diabetes still not formally recommended unlike in type two diabetes. ${ }^{11-12}$

The current review aimed to summarize the RCTs that investigate clinical benefits of metformin as an adjunctive add on medication to insulin in type 1 diabetes mellitus.

\section{Method}

A systematic electronic search was conducted including the Pub Med, Google Scholar, and EBSCO using the following terms in different combinations: metformin, diabetes, HA1c, and $\mathrm{C}$ - peptide. We included all full texts randomized controlled trials investigated the effect of metformin as an adjuvant therapy in type 1 diabetes. Studies published in abstracts were not included. Two hundred and four articles were identified, only six of them fulfilled the inclusion and exclusion criteria. The abstracts and full texts were screened independently by two authors (MA, Al). The authors extracted the data, and then the author's names, year and region of publication, the study type, period of study, and the result were reported (Table1). The PRISMA Chart was used in the current survey (Figure 1).

\section{Results}

A systematic electronic search was conducted including the Pub Med, Google Scholar, and EBSCO using the following terms in different combinations metformin, diabetes, HA1c, and C- peptide. Randomized controlled trials in full text that assessed the role of adjuvant metformin therapy on glycaemic control in type 1 diabetic patients were included. Two hundred and four articles were identified, only six of them fulfilled the inclusion and exclusion criteria. The abstracts and full texts were screened independently by two authors (AI,MA). The authors extracted the data, and then the author's names, year and region of publication, the study type, period of study, and the result were reported (Table 1). The PRISMA Chart was used in the current survey (Figure 1).

A total of 391 patients were enrolled. The duration of metformin therapy was three months or more. The metformin dosages among the studies varied, with the total dosage varying from 1000-2000mg per day. In view of glycaemic control assessment, as indicated by HA1c reduction, among the trials, a contradictory results were found between the studies, as illustration, Hamilton et al. ${ }^{13}$ shows that in type 1 diabetic patients with insulin requirement $\geq 1$ unit per $\mathrm{kg}$, metformin successfully result in a significant reduction in $\mathrm{HbA1c}$, TIDD, FBS. Similarly, Khan et al. $^{14}$ In a randomized, double-blind, cross-over study. Compared to placebo, metformin significantly reduces HbA1c from 8.5-7.8 (P<0.005), lower FBS $(12.4$ vs. $8.3 \mathrm{mmol} / \mathrm{I})$, and TDID. On the other hand, this beneficial effect of adjuvant metformin on $\mathrm{HbA1c}$ redaction was not observed in four out of the six trials, ${ }^{15-18}$ despite the significant reduction in the total insulin daily dose requirement and the significant weight reduction. ${ }^{15-18}$ Land et al conduct a randomized, double-masked, parallel trial, to study the effect of metformin of both HA1c and FBS in type 1 diabetic patients, after 12 months follow up period of 98 adult (aged 18 years or more) with uncontrolled diabetes control (HA1c of 8.5 per cent or more), and the study show a significant decrease in the TDD and weight without change in HA1C value. ${ }^{15}$ Alike, Jacobsen et al., in randomized control study, conclude that metformin can reduce TDD but not the HA1c. ${ }^{16}$ Similar finding also concluded from the last two RCTs. ${ }^{17-18}$ 


\section{Discussion}

In this review of six trials aimed to evaluate the effect of metformin on glycaemic control in type 1 diabetic patients. The primary endpoint was assessment of whether metformin as an adjuvant therapy will affect glycaemic control (by Ha1c, fasting blood sugar (FBS)), insulin sensitivity (by total insulin daily dose (TIDD)). ${ }^{13-18}$

The American Diabetes Association (ADA) recommends an $\mathrm{HbA1c}$ goal of $<7$ per cent across all paediatric age-groups. Such a reduction was associated with reduction in both microvascular and macrovascular complications in T1DM. ${ }^{4}$

Participants heterogeneity in form of different baseline HA1c, different in metformin dosage as well as lake of standardized insulin dose adjustment protocol, cloud explain this contradictory result.

Comparing with non-diabetic, type 1 diabetic patients had insulin resistance as shown on several studies documented by measuring hyperinsulinemic euglycemic clamp. Of note, this resistance not only associated obesity, as even a normal weight type 1 diabetic patients had a significant decrease in insulin sensitivity. ${ }^{19,20}$

Improve insulin sensitivity, one of pharmacological properties of metformin. A reduction of the total daily insulin dose was concluded from the six trials. ${ }^{14-19}$ Furthermore, Bjornstad et al. ${ }^{21}$ conduct a placebocontrolled, double-blinded, randomized control trial, where metformin at dose of $2 \mathrm{~g}$ where compared to placebo. The study shows an improvement in insulin resistance along with reduction in the total daily insulin dose.

\section{Conclusion}

The current review demonstrates that administering adjunctive metformin therapy in type 1 diabetic patients associated with modest reduction in HA1c, improve insulin resistance as indicated by reduce daily insulin requirement.

\section{References}

1. Molitch ME, Steffes MW, Cleary PA, et al. Baseline analysis of renal function in the Diabetes Control and Complications Trial. The Diabetes Control and Complications Trial Research Group [corrected]. Kidney Int. 1993;43:668.

2. Dahl-Jørgensen $K$, Bjøro $T$, Kierulf $P$, et al. Long-term glycemic control and kidney function in insulindependent diabetes mellitus. Kidney Int. 1992;41:920.

3. Barzilay J, Warram JH, Bak M, et al. Predisposition to hypertension: risk factor for nephropathy and hypertension in IDDM. Kidney Int. 1992;41:723.

4. American Diabetes Association. 13. Children and Adolescents: Standards of Medical Care in Diabetes-2020. Diabetes Care. 2019;43(Supplement 1), pp.S163-S182.

5. Katsarou A, Gudbjörnsdottir S, Rawshani A, et al. Type 1 Diabetes Mellitus. Nat Rev Dis Primers. 2017;3:17016.

6. Weinstock RS, Schütz-Fuhrmann I, Connor CG, et al. T1D Exchange Clinic Network; DPV Initiative. Type 1 diabetes in older adults: comparing treatments and chronic complications in the United States T1D Exchange and the German/Austrian DPV registries. Diabetes Res Clin Pract. 2016;122:28-37.

7. Frandsen CS, Dejgaard TF, Madsbad S. Non-insulin drugs to treat hyperglycaemia in type 1 diabetes mellitus. Lancet Diabetes Endocrinol. 2016;4:766-780.

8. Sorensen JS, Birkebaek NH, Bjerre $\mathrm{M}$, et al. Residual $\beta$ cell function and the insulin-like growth factor system in Danish children and adolescents with type 1 diabetes. J Clin Endocrinol Metab. 2015;100:1053-61.

9. Dejgaard TF, Knop FK, Tarnow L, et al. Efficacy and safety of the glucagon-like peptide-1receptor agonist liraglutide added to insulin therapy in poorly regulated patients with type 1 diabetes-a protocol for a randomised, double-blind, placebo-controlled study: the Lira-1 study. BMJ Open. 2015;5:e007791.

10. UK Prospective Diabetes Study (UKPDS) Group. Effect of intensive blood-glucose control with metformin on complications in overweight patients with type 2 diabetes (UKPDS 34). Lancet. 1998;352:854-65.

11. Konrad K, Datz N, Engelsberger I, et al. Current use of metforminin addition to insulin in pediatric patients with type 1 diabetes mellitus: an analysis based on a large diabetes registry in Germany and Austria. Pediatr Diabetes. 2015;16:529-37.

12. DeGeeter $M$, Williamson B. Alternative agents in type 1 diabetes in additionto insulin therapy: Metformin, alphaGlucosidase inhibitors, Pioglitazone, GLP-1 agonists, DPP-IV inhibitors, and SGLT-2 inhibitors. J. Pharm Pract. 2016;29(2):144-59.

13. Hamilton J, Cummings E, Zdravkovic V, et al. Metformin as an adjunct therapy in adolescents with type 1 diabetes and insulin resistance: a randomized controlled trial. Diabetes Care. 2003;26:138-43.

14. Khan AS, McLoughney CR, Ahmed AB. The effect of metformin on blood glucose control in overweight patients with Type 1 diabetes. Diabet Med. 2006;23:1079-84.

15. Lund SS, Tarnow L, Astrup AS, et al. Effect of adjunct metformin treatment in patients with type-1 diabetes 
and persistent inadequate glycaemic control. A randomized study. PLoS ONE. 2008;3(10):e3363. doi:10.1371/journal.pone.0003363

16. Jacobsen IB, Henriksen JE, Beck-Nielsen H. The effect of metformin in overweight patients with type 1 diabetes and poor metabolic control. Basic Clin Pharmacol Toxicol. 2009;105:145-9.

17. Nadeau KJ, Chow K, Alam S, et al. Effects of low dose metformin in adolescents with type I diabetes mellitus: a randomized, double-blinded placebo-controlled study. Pediatr Diabetes. 2015;16:196-203. doi:10.1111/pedi.12140

18. Libman IM, Miller KM, DiMeglio LA, et al. Effect of metformin added to insulin on glycemic control among overweight/obese adolescents with type 1 diabetes: $A$ randomized clinical tTrial. JAMA. 2015;314(21):22412250. doi:10.1001/jama.2015.16174

19. Nadeau KJ, Regensteiner JG, Bauer TA, et al. Insulin resistance in adolescents with type 1 diabetes and its relationship to cardiovascular function. J Clin Endocrinol Metab. 2010;95:513-521. [PubMed: 19915016]

20. Cree-Green M, Newcomer BR, Brown MS, et al. Delayed skeletal muscle mitochondrial ADP recovery in youth with type 1 diabetes relates to muscle insulin resistance. Diabetes. 2015;64:383-392. [PubMed: 25157095]

21. Bjornstad $P$, Schafer $M$, Truong $U$, et al. Metformin improves insulin sensitivity and vascular health in youth with type 1 diabetes mellitus: randomized controlled trial. Circulation. 2018;138:2895-2907.

\section{PEER REVIEW}

Not commissioned. Externally peer reviewed.

\section{CONFLICTS OF INTEREST}

The authors declare that they have no competing interests.

\section{FUNDING}

None 
Table 1: Randomized trials that investigate the role of metformin as an adjuvant therapy in type 1 diabetes

\begin{tabular}{|c|c|c|c|}
\hline & $\begin{array}{l}\text { Author- } \\
\text { Publication } \\
\text { date }\end{array}$ & Methods & Results \\
\hline 1 & $\begin{array}{l}\text { Hamilton et } \\
\text { al. }^{13}\end{array}$ & $\begin{array}{l}\text { Study design: Randomized, placebo- } \\
\text { controlled trial. } \\
\text { Inclusion criteria: age } 12-17 \text { years; Tanner } \\
\text { stage } 2-5 \text {; diagnosed } 3 \text { years or more; } \\
\text { HbA1c } \geq 8.0 \text { for the prior } 6 \text { months; and } \\
\text { insulin dosage } \geq 1 \text { unit per kg. } \\
\text { Interventional group: Metformin } 500 \mathrm{mg} \\
\text { titrated to the maximum dose. } \\
\text { Follow-up: } 3 \text { months } \\
\text { Primary objective: To evaluate the effect of } \\
\text { metformin on insulin sensitivity, HbA1c, } \\
\text { fasting glucose, insulin dosage and BMI. }\end{array}$ & $\begin{array}{l}\text { Study completer: } 27 \text { patients. } \\
\text { Results: A significant reduction in HbA1c, TDD, FBS } \\
\text { with increase in mild hypoglycemia in metformin } \\
\text { group, with no significant change in BMI, severe } \\
\text { hypoglycemic episodes or gastrointestinal complaints } \\
\text { between the two groups. } \\
\text { Conclusion: Metformin treatment lowered HbA1c and } \\
\text { decreased insulin dosage with no weight gain in teens } \\
\text { with type } 1 \text { diabetes in poor metabolic control. }\end{array}$ \\
\hline 2 & Khan et al. ${ }^{14}$ & $\begin{array}{l}\text { Study design: Randomized, double-blind, } \\
\text { cross-over study. } \\
\text { Inclusion criteria: C-peptide negative } \\
\text { diabetic patients for more than } 1 \text { year, with } \\
\text { overweight (BMI) }>27 \mathrm{~kg} / \mathrm{m}^{2} \text {, and had been } \\
\text { stable on insulin therapy with a baseline } \\
\text { HbA1c } 6.1 \% \\
\text { Interventional group: Insulin plus either } \\
\text { Metformin } 850 \mathrm{mg} \text { per day titrated every } \\
\text { week to the maximum } 850 \mathrm{mg} \text { trice a day or } \\
\text { placebo. } \\
\text { Follow-up: } 16 \text { weeks } \\
\text { Primary objective: investigate the effect of } \\
\text { metformin on blood glucose control and } \\
\text { daily insulin dose }\end{array}$ & $\begin{array}{l}\text { Study completer: } 15 \text { patients } \\
\text { Results: Comparing metformin to placebo statically } \\
\text { significant HbA1c, FBS and TDD. While no change in } \\
\text { body weight, lipid profile, incidence of hypoglycemia. } \\
\text { Conclusion: Metformin can effectively improve } \\
\text { glycemic control and reduce the total daily insulin } \\
\text { dose in overweight people with Type } 1 \text { diabetes. }\end{array}$ \\
\hline 3 & Land $^{15}$ & $\begin{array}{l}\text { Study design: Single-center, randomized, } \\
\text { double-masked, parallel trial. } \\
\text { Inclusion criteria: Adult ( } \geq 18.0 \text { years) with } \\
\text { TIDM for } 5 \text { years or more, an average HA1c } \\
\text { of } 8.5 \% \text { or more. } \\
\text { Interventional group: Metformin } 500 \mathrm{mg} \\
\text { daily, titrated weekly to } 2 \mathrm{~g} \text { per day. } \\
\text { Follow-up: } 12 \text { months } \\
\text { Primary objective: evaluate the effect of } \\
\text { metformin on HA1c. }\end{array}$ & $\begin{array}{l}\text { Study completer: } 98 \text { patients. } \\
\text { Results: Significant reduction in TIDD and Wight. } \\
\text { While a non-significant change in HA1C, occurrence of } \\
\text { hypoglycemia. } \\
\text { Conclusion: In patients with poorly controlled T1DM, } \\
\text { adjunct metformin therapy did not provide any } \\
\text { improvement of glycemic control after one year. }\end{array}$ \\
\hline 4 & $\begin{array}{l}\text { Jacobsen et } \\
\text { al. }^{16}\end{array}$ & $\begin{array}{l}\text { Study design: Double-blinded, randomized, } \\
\text { parallel group study. } \\
\text { Inclusion criteria: type } 1 \text { diabetes for at } \\
\text { least } 1 \text { year (plasma C-peptide }<5 \text { ), age } 18- \\
60 \text { years with BMI }>25 \mathrm{~kg} / \mathrm{m}^{2} \text { and HbA1c } \\
\geq 8.0 \text {. } \\
\text { Interventional group: basal-bolus insulin } \\
\text { regimen plus either }\end{array}$ & $\begin{array}{l}\text { Study completer: } 23 \text { patients } \\
\text { Results: In metformin group, significant reduction in } \\
\text { TDD, weight and increased incidence of hypoglycemia. } \\
\text { While no change in HbA1c, lipid profile. } \\
\text { Conclusion: Metformin, as adjunct to intensive insulin } \\
\text { therapy, was associated with a reduction in the total } \\
\text { daily insulin dose and a significant weight loss in } \\
\text { patients with type } 1 \text { diabetes mellitus. }\end{array}$ \\
\hline
\end{tabular}




\begin{tabular}{|c|c|c|c|}
\hline & & $\begin{array}{l}\text { Metformin } 500 \mathrm{mg} \text { twice daily for } 2 \text { weeks } \\
\text { followed by Metformin } 1000 \mathrm{mg} \text { twice daily } \\
\text { or placebo } \\
\text { Follow-up: } 24 \text { weeks } \\
\text { Primary objective: Metformin effect on } \\
\text { HbA1c. }\end{array}$ & \\
\hline 5 & $\begin{array}{l}\text { Nadeau et } \\
\text { al. }^{17} \\
2015\end{array}$ & $\begin{array}{l}\text { Study design: Randomized, double-blinded, } \\
\text { placebo-controlled trial } \\
\text { Inclusion criteria: To test the effects of } \\
\text { metformin in adolescents with T1DM. } \\
\text { Interventional group: Metformin 1g per day. } \\
\text { Follow-up: } 6 \text { months } \\
\text { Primary objective: change in HbA1c. }\end{array}$ & $\begin{array}{l}\text { Study completer: } 59 \text { patients. } \\
\text { Results: Significant reduction in weight and TIDD. } \\
\text { While a non-significant change in HA1c. } \\
\text { Conclusion: Low-dose metformin likely improves BMI } \\
\text { as well as insulin sensitivity in T1DM adolescents, }\end{array}$ \\
\hline 6 & $\begin{array}{l}\text { Libman et al. }^{18} \\
2015\end{array}$ & $\begin{array}{l}\text { Study design: Multicenter, double-blind, } \\
\text { placebo-controlled randomized clinical trial. } \\
\text { Inclusion criteria: T1DM on insulin aged } \\
\text { between } 12-20 \text { years. } \\
\text { Interventional group: Metformin } 500 \mathrm{mg} \\
\text { daily, titrated weekly to } 2 \mathrm{~g} \text { per day. } \\
\text { Follow-up: } 4 \text { months. } \\
\text { Primary objective: change in HAlc. }\end{array}$ & $\begin{array}{l}\text { Study completer: } 169 \text { patients. } \\
\text { Results: Significant reduction in weight and TIDD. } \\
\text { While a non-significant change in HA1c. } \\
\text { Conclusion: Among overweight adolescents with type } \\
1 \text { diabetes, the addition of metformin to insulin did } \\
\text { not improve glycemic control. }\end{array}$ \\
\hline
\end{tabular}


Figure 1: Flow diagram through the different phases of the systematic review (PRISMA flowchart)
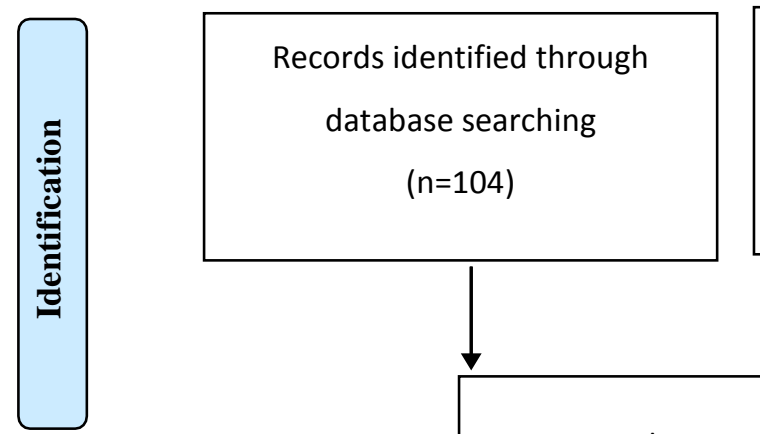

Additional records identified

through other sources $(n=0)$;

no other sources

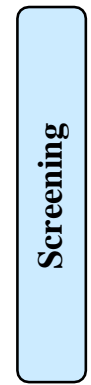

Records screened $(n=77)$
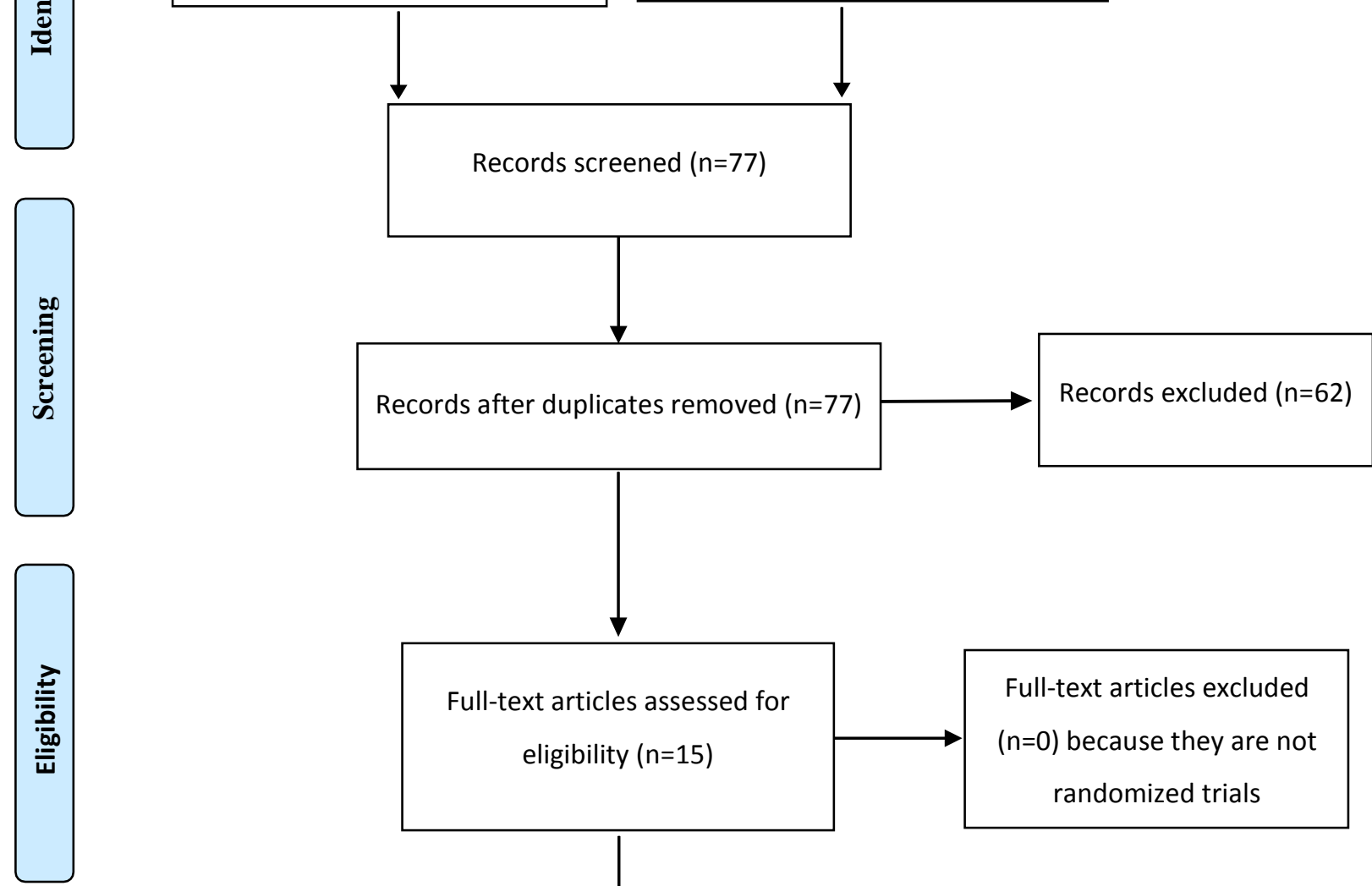

里

Studies included in the qualitative synthesis $(n=6)$ 